\title{
Anglo-American Economic Diplomacy during World War II and the Electrification of the Central Brazilian Railway
}

Abstract: Throughout the Second World War British and American companies competed to gain the contract for the electrification of the central Brazilian railway.

The British Foreign Office used this case to establish a broader principle with the US government that the conditions brought about by war would not be used by one country to gain commercial advantage at the expense of the other. While the US government supported this principle in theory, this article argues that they failed to adhere to it in practice. US actions in this case shed new light on the country's economic diplomacy with Britain during World War II.

Beyond short-term measures aimed at winning the war, the major theme of the economic diplomacy between the United States and Great Britain during the Second World War was the economic shape of the postwar world. The most prominent aspect of this diplomacy was an attempt by the US State Department to break open Britain's closed trade regime - based on the sterling bloc and the imperial preference system and replace it with its own liberal model - based on equality of access to global markets and resources. These efforts achieved a degree of success in August 1941 when point four of the Atlantic Charter declared that the US and Britain would endeavor to ensure future equal access, for all countries, 'to trade and to the raw materials of the world which are needed for their economic prosperity'. ${ }^{1}$ The Master Lend-Lease Agreement, signed the following February, further pledged that the US and Britain would work towards 'the elimination of all forms of discriminatory treatment in international commerce, and to the reduction of tariffs and other barriers to trade' ${ }^{2}$

The traditional interpretation of this process depicted US efforts to install a liberal trade system as a prerequisite to achieving future international stability and 


\section{Anglo-American Economic Diplomacy during World War II and the Electrification of the Central Brazilian Railway}

peace. Writing in his memoirs, the chief architect of this system, US Secretary of State, Cordell Hull, described how the freer trade achieved by nations under a global system based on economic liberalism would lead to greater prosperity for all. Such prosperity, he believed, would eliminate the economic dissatisfaction that had allowed the rise of the dictatorial regimes responsible for taking the world to war. ${ }^{3}$ Given British control of large swathes of world trade, it was essential for US officials to gain their wartime ally's support for a liberal trade system if the economic foundations for peace were to be securely laid.

Writing in the 1960's revisionist scholars described less altruistic motives fuelling US economic aims. Pointing to US economic superiority by the time of the Second World War, they noted that the equality of opportunity afforded under the US trade program principally acted to advance the country's own economic interests. Pitched against British scarcity under the duress of war, the US desire to promote a liberal trade system in this interpretation looked more like an opportunistic attempt to challenge British economic power. ${ }^{4}$

More recently, a small number of studies have re-examined the shared assumption that united previous interpretations of Anglo-American economic diplomacy in World War II: the US commitment to a liberal trade system. Both by revisiting the negotiations between the two countries concerning the general economic structure of the postwar world, and by exploring specific instances of AngloAmerican competition during the war, these authors have demonstrated the failure of the US to consistently pursue a liberal trade system for the postwar era in its diplomacy with Britain. ${ }^{5}$ They have therefore suggested the need to re-characterize the true nature of US economic aims toward Britain during World War II. 


\section{Anglo-American Economic Diplomacy during World War II and the Electrification of the Central Brazilian Railway}

This article considers Anglo-American competition concerning the electrification of the central Brazilian railway. The diplomacy between the two countries concerning this particular venture was not of great importance in itself. But as this article will seek to show, the negotiations took on significance beyond their own intrinsic worth, as the British Foreign Office used the case to try and establish a broader principle with the US government that the unique conditions brought about by the war would not be used by one country to try and gain commercial advantage for the postwar era at the expense of the other. Protection of British export markets was deemed by the British government to be an essential prerequisite of the country effectively participating in the kind of liberal trade system that the State Department wished to see take shape in the postwar world. For if these markets were not retained for the postwar era, such a system would not provide Britain the means to ensure a favorable balance of payments, which would be essential for the basic economic health of the country.

While the Foreign Office was successful in enlisting the theoretical support of the US government for this principle, the outcome of the competition for this enterprise demonstrates that the US government and its nationals failed to adhere to the principle in practice. Rather, US policy in this instance aimed to advance the country's own short-term commercial interests, and in the process, exclude Britain's commercial footholds in Brazil. In failing to uphold the agreement reached with Britain, the US government actively undermined the State Department's stated goal of implementing a liberal trade order for the postwar world by depriving Britain of the export markets it would need to participate in this system. Moreover, when seeking to achieve its aims in this case the US government tended to employ whichever methods 


\section{Anglo-American Economic Diplomacy during World War II and the Electrification of the Central Brazilian Railway}

were most effective, regardless of whether they were compatible with the State

Department's broader efforts to implement a liberal trade system.

To the extent that it was economic self-interest guiding US diplomacy with Britain, and that World War II offered an opportunity for the US to take advantage of British scarcity, this case supports previous revisionist interpretations. However, this case diverges from the pattern portrayed by revisionists whereby the US advocated a liberal trade system in order to prize open Britain's closed trade regime. Rather, by promoting its own narrow interests and excluding Britain from participating in postwar trade, US actions in this case worked to the detriment of instituting a liberal economic order for the postwar years. As such, this study affirms the need to reconsider US ambitions in its wartime diplomacy with Britain.

The general framework within which US economic policy toward Brazil took place during the war was to encourage the industrial development of the country. In 1942 Morris L. Cooke led a technical mission to investigate the possibilities for promoting such development. Reflecting on US-Brazilian trade in his subsequent book on the country, Cooke quoted a study by the National Association of Manufacturers to illustrate the mutual benefits to be obtained from Brazilian development. The study stated the truism that 'the economic value of trade between the United States and other countries increases in proportion to the development of the countries with which we trade'. As well as satisfying Brazilian desires, then, the US policy to encourage the industrial development of Brazil during the war would also increase the country's demand for imports, thereby providing the US with an expanded export market for the postwar years. ${ }^{6}$

Despite the increasing dominance of the US in Brazil by the time of the Second World War, the country still provided British industry with an important 


\section{Anglo-American Economic Diplomacy during World War II and the Electrification of the Central Brazilian Railway}

export market for steel and electrical manufactures. ${ }^{7}$ Moreover, this market was predicted to be one of the fastest growing consumers of such goods in the postwar years. ${ }^{8}$ Throughout the war, British officials looked to the Brazilian market as an essential future component of the planned export drive that would allow Britain to achieve a positive balance of payments in the postwar era. ${ }^{9}$ If Brazil were to play this role in Britain's postwar economic policy it was essential that the established markets for British goods were maintained throughout the war years.

Both British and US economic objectives toward Brazil led to a focus throughout the war years on the ongoing electrification of the central Brazilian railway. For Britain, this was a substantial contract that would firmly secure British manufacturing interests in the Brazilian market; for the US, this project was a major plank of Brazil's industrial development.

The central Brazilian railway was a government owned utility within the Ministry for Transportation and Public Works. Stretching over 1,500 kilometers from the interior states of Minas Gerais and São Paulo to Rio de Janeiro on the coast, the railway was the country's principal mode of transport for both people and goods. ${ }^{10}$ In particular, it transported iron ore and manganese from a mine at Minas Gerais to Rio, where it could be shipped for export. The Director of the railway, Major Napoleão de Alencastro Guimarães, went so far in his estimation of its magnitude to claim that 'by virtue of the extent and position of its system the Central is unquestionably the most important railway not only in Brazil but also in South America'. ${ }^{11}$ While not a wholly impartial observer, Guimarães' statement did reflect the significance of the railway for Brazil's infrastructure.

The conversion of the central railway from steam to electric operation was part of the broader industrialization of the country administered by Getúlio Vargas, the 


\section{Anglo-American Economic Diplomacy during World War II and the Electrification of the Central Brazilian Railway}

President of Brazil since $1930 .{ }^{12}$ Foreign interest in the contract to carry out the work went back even further to 1908, when the US firm General Electric sent a team of experts to Brazil to draw up plans for the project. World War I interrupted the implementation of these proposals, but in 1922 the US firm gained a contract to carry out the project. However, the funds supplied by a US bank to finance the scheme were mysteriously diverted to other purposes and the contract was shelved. When in 1932 the Brazilian authorities again called for tenders for the project, General Electric was outbid by their British competitors, the Manchester-based manufacturing firm, Metropolitan-Vickers. ${ }^{13}$

During the negotiations over the contract that followed, Metropolitan-Vickers and the Brazilian authorities decided to divide the project into an initial section of 35 kilometers, stretching from Rio to Nova Iguassu, and a further section of 73 kilometers, extending the line to Barra do Piraí. From 1935 to 1937 the British company successfully completed the electrification of the first section and looked toward the completion of the line. However, disagreements over prices and the exact nature of the materials to be provided delayed conclusion of the project. In 1940 the Brazilian authorities therefore issued a new tender for contracts to complete the second section of the railway. ${ }^{14}$ Securing this contract took on significance beyond the sum total of its parts, as it was widely predicted that whichever company established the technical standards and specifications for this section of the line would likely be guaranteed work on the remainder of the railway system, and possibly the bulk of Brazil's railway infrastructure for the foreseeable future. ${ }^{15}$

It was with these factors in mind that the Foreign Office backed MetropolitanVickers' tender for the contract and urged the Treasury and Board of Trade to guarantee the necessary financial support and supplies for the project. ${ }^{16}$ The British 


\section{Anglo-American Economic Diplomacy during World War II and the Electrification of the Central Brazilian Railway}

ministries were originally forthcoming in this support. However, world war again disrupted the electrification scheme and in April 1941 the British government withdrew its backing for the enterprise due to a war-induced lack of raw materials and manpower. $^{17}$

The failure of a successful tender for the new contract meant MetropolitanVickers' option to complete the electrification of the line contained in the original contract remained valid. However, having lost the support of the British government to complete the work, the company was well aware of the vulnerability of their contract; more specifically, they were immediately alive to the danger posed by US competition. ${ }^{18}$ In order to try to stifle this competition the British firm decided not immediately to inform the Brazilians of their inability to fulfill the contract during the war in the hope that supply conditions in the US would worsen, placing US companies in the same predicament as themselves. ${ }^{19}$ While achieving their objective in the short term, such tactics also left Metropolitan-Vickers open to criticism from within the US. An article in Time magazine complained that the company's efforts to keep General Electric from gaining the contract had left the work on the railway unfinished indefinitely. ${ }^{20}$ The President of the US Export-Import Bank, Warren Lee Pierson, lent official voice to this criticism, deriding the British government for allowing such underhand tactics. ${ }^{21}$

These attacks on Metropolitan-Vickers and the British government were part of a broader tide of criticism concerning British trade practices in South America emanating from the US throughout the summer of 1941. The broad thrust of these criticisms concerned the Lend-Lease program, whereby the US government supplied Britain with much-needed war materials. Shortly after the passing of the Lend-Lease Act by Congress on 11 March 1941, US businessmen, based in South America, 


\section{Anglo-American Economic Diplomacy during World War II and the Electrification of the Central Brazilian Railway}

charged Britain with re-exporting materials received under Lend-Lease in order that British firms might compete with their US counterparts in the region. ${ }^{22}$ Such use of Lend-Lease for commercial gain, rather than the intended purpose of contributing to the war effort, was obviously deemed misuse of the aid. The complaints from US business entered the public domain when the New York Times ran a story in July repeating the accusations. ${ }^{23} \mathrm{~A}$ few days later the objections gained political representation when Congressman James Francis O'Connor introduced a resolution into the House of Representatives calling for an investigation into British trade practices in South America. $^{24}$

The investigation never got off the ground, and in reality the claim that British industry was profiting in South America off the back of Lend-Lease was a spurious one. British exports to the region had by this time been drastically curtailed and while a small amount of trade was continued with Argentina, this served a legitimate wartime necessity. ${ }^{25}$ This was certainly the view held by President Franklin D. Roosevelt when he dismissed the accusations against the British in an August press conference. ${ }^{26}$ Indeed, the President and his advisers generally regarded such accusations as a political weapon being employed by the domestic opponents of the aid program. ${ }^{27}$ But regardless of the motivations behind the allegations, both British and US officials were well aware of the potential danger such criticism posed to the continuation of the aid program. Lend-Lease was subject to annual renewal by Congress, so the maintenance of public support for the aid was a top priority.

Mindful of this necessity the British government took steps throughout the summer of 1941 to deflect the criticism being aimed at its trade practices in South America. Unfortunately for Metropolitan-Vickers, their Brazilian venture was sacrificed as part of this effort. On 3 July the Foreign Office under-cut the company's 


\section{Anglo-American Economic Diplomacy during World War II and the Electrification of the Central Brazilian Railway}

delaying tactics and Sir Geoffrey Knox, the British Ambassador in Rio, informed the Brazilian authorities directly of the government's inability to support the electrification scheme at the present time. ${ }^{28}$ Later that month, John Maynard Keynes, who was visiting Washington as a representative of the British Treasury, made a statement defending Britain against the claims that Lend-Lease was being misused for commercial gain. In his statement Keynes specifically cited the company’s 'abandonment' of the electrification scheme as proof of Britain's curtailment of exports to South America. ${ }^{29}$

The culmination of British attempts to pacify the criticism of its alleged misuse of Lend-Lease was the publication on 10 September 1941 of the British Export White Paper. This statement of policy, announced by Foreign Secretary Anthony Eden in Parliament, committed Britain not to use material received under Lend-Lease 'in such a way as to enable their exporters to enter new markets or to extend their export trade at the expense of the United States exporters' ${ }^{30}$ This statement of policy represented a formal political bar to Metropolitan-Vickers completing the work on the Brazilian railway, beyond the war-induced supply shortages impeding Britain's export trade.

Sir Felix Pole, the chairman of Metropolitan-Vickers' parent company, Associated Electrical Industries, lambasted the British government for callously abandoning its interests in South America, but British officials turned a deaf ear to his complaints for fear of further inflaming Anglophobe sentiment in the US. ${ }^{31}$ Indeed, from April 1941, when the British government first withdrew its support for the project, government officials maintained a hostile attitude toward the company and its Brazilian venture. ${ }^{32}$ At best, the British government viewed the project as an unwanted diversion from more important business; at worse, they viewed it as threat 


\section{Anglo-American Economic Diplomacy during World War II and the Electrification of the Central Brazilian Railway}

to Anglo-American unity at a time when the goodwill of the US was an indispensable asset.

The Japanese attack on Pearl Harbor and the subsequent US entry into the war fundamentally altered the atmosphere in which Anglo-American diplomacy was conducted. The day after the US became a fully-fledged belligerent, one of the British Chiefs of Staff suggested a more deferential tone be employed in a message to the US. Prime Minister Winston Churchill replied: 'Oh! that is the way we talked to her when we were wooing her; now that she is in the harem, we talk to her quite differently'. ${ }^{33}$ It was in this context that the British government started to change its attitude toward both Metropolitan-Vickers and, in turn, the US government, with regard to the central Brazilian railway. The more immediate instance for this change of heart was reports from Brazil that a US firm was attempting to take advantage of restrictions on British exports to try and gain the electrification contract for themselves. ${ }^{34}$

On 4 September 1942 the New York-based Electrical Export Corporation - an export consortium composed of General Electric and Westinghouse International submitted a proposal to undertake the work previously contracted to MetropolitanVickers. ${ }^{35}$ By the end of November a judging commission had given favorable consideration to the proposal and negotiations between the Brazilian authorities and the US company were well under way. ${ }^{36}$ The chief fear of Henry Walter Foy, Metropolitan-Vickers' representative in Rio, was that the US firm would gain the contract on the pretence that it could carry out the work during the war, only to postpone it for postwar completion. What the company therefore requested of the Foreign Office was that they ask the State Department to restrain US industrial interests from intriguing after the contract. ${ }^{37}$ 


\section{Anglo-American Economic Diplomacy during World War II and the Electrification of the Central Brazilian Railway}

The realization that Metropolitan-Vickers might permanently lose this important enterprise to their US competitors prompted the British authorities to take a more sympathetic attitude toward the company and adopt a firmer stance vis-à-vis the State Department. ${ }^{38}$ But in choosing to adopt this course of action the Foreign Office had much greater aspirations in mind than the Brazilian railway alone. Sir Edward Mather-Jackson, the official in charge of economic affairs in the South American department of the Foreign Office, explained that the broader goal he hoped to achieve was 'an understanding with the United States authorities that the United States industries should not receive any encouragement from their Government to take away business which we are prevented from undertaking because of the war'. ${ }^{39}$ In this sense, the Foreign Office hoped to use the case of the electrification of the central Brazilian railway to extract a 'self-denying ordinance' from the State Department that would protect British commercial interests generally for the postwar era. ${ }^{40}$

The British Ambassador in Washington, Lord Halifax, consequently took the matter up with the US authorities, enquiring both whether the Board of Economic Warfare (BEW) would be able to release the necessary supplies for the work and whether the Export-Import Bank was planning to finance the project. ${ }^{41}$ On the first point BEW noted the strategic value of the iron ore and manganese transported on the railway, but did not consider electrification of the line a war necessity. They therefore thought it unlikely that any application for the project would gain approval at the present time. ${ }^{42}$ Moreover, the State Department agreed to make this supply situation clear, both to the Electrical Export Corporation and the Brazilian authorities. ${ }^{43}$ On the second point it was denied that any loan from the Export-Import Bank had been guaranteed for the project, but it was confirmed that Pierson had given verbal undertakings that the bank would be willing to support the scheme in the future. ${ }^{44}$ 


\section{Anglo-American Economic Diplomacy during World War II and the Electrification of the Central Brazilian Railway}

While this may have been a more sympathetic reply than British officials had expected, the US response to the protest focused narrowly on the specifics of the case in hand. The State Department was well aware of the broader question raised by the British request: would it prevent a US company from taking a contract that would have been held by their British competitor, had it not been for the war. ${ }^{45}$ The failure on their part to address this broader question reflected an unwillingness to take a firm position on the matter at this time. ${ }^{46}$ Considering the British protest, Emilio G. Collado, Special Assistant to the Under-Secretary of State, admitted that it seemed impossible that the Electrical Export Corporation would be able to complete the work during the war, but insisted that it was legitimate for them to 'line up projects for immediate execution after the war'. He further maintained the right of 'the ExportImport Bank to enter into arrangements looking forward to such a period' ${ }^{47}$ Such an attitude within the State Department made any firm commitment that the US company would not benefit from the dislocations affecting British commerce, impossible to give.

Having failed to establish a broader principle protecting British interests via a protest to the US government relating to a specific case, the Foreign Office opted to approach the issue head-on at the highest level. In an Aide-Memoire handed to Hull by Halifax on 10 July 1943, the Foreign Office directly linked a request for selfrestraint on the part of the US government to the State Department's own economic plans for the postwar world. Expressing an awareness 'that the United States Government regard the extension of postwar trade as the common objective', it went on to express the hope that the US government shared with its wartime ally, 'the view that Great Britain should participate in this expansion in markets generally, including those in Latin America'. Pointing to the curtailment of British exports to Latin 


\section{Anglo-American Economic Diplomacy during World War II and the Electrification of the Central Brazilian Railway}

America entailed by war sacrifices, alongside US efforts to promote their own export trade in the region, the Aide-Memoire described 'an impression, however false, that there may be some desire on the American side to supplant British traders in [their] established and traditional markets, not only for the war period, but permanently thereafter' ${ }^{48}$ In order to counteract this notion Halifax asked Hull if the US government would agree to 'the principle that no advantage in world markets shall accrue to either country at the expense of the other by reason of sacrifices made in the interest of the effective prosecution of the war'. By linking the protection of British markets to the country's ability to participate effectively in the liberal trade regime the State Department wished to see take shape in the postwar era, the Foreign Office made a request that Hull could scarcely reject. He subsequently denied there was any intention on the part of the US to purge British interests from Latin America and pledged US agreement to the principle protecting British interests more broadly. ${ }^{49}$

This agreement on general policy provided the British government with a new framework within which subsequent efforts to protect Metropolitan-Vickers' interests in Brazil could take place. This remained a key objective for the Foreign Office, for although they had been successful in winning official support for a principle to protect British interests, the outcome of the case that had first raised the issue would now act as a barometer of the extent to which the US government would abide by this principle in practice. Mather-Jackson made this clear, explaining that the principle had 'become inseparable in the minds of the US authorities from the case in point' ${ }^{50}$ The necessity to test the new Anglo-American agreement arose just days after its consummation.

On 13 July the Brazilian Minister for Foreign Affairs, Oswaldo Aranha, informed the new British Ambassador in Rio, Sir Noel Charles, that negotiations with 


\section{Anglo-American Economic Diplomacy during World War II and the Electrification of the Central Brazilian Railway}

the British company concerning the electrification of the second section of the railway would have to be broken due to the need to proceed with the work 'without further delay'. Charles expressed dismay on receiving this news but nonetheless accepted the Brazilian's decision, asking only that further work on the railway be reserved for the British company as compensation for losing out on the present phase. ${ }^{51}$ But while this may have been a suitable response when viewing the case solely through the prism of British interests in Brazil, it failed to take into the account the significance the Brazilian enterprise had taken on in Anglo-American economic diplomacy. From the perspective of the Foreign Office, to accept the loss of this contract to a US firm would constitute a failure to uphold the new agreement protecting British interests more broadly. As Mather-Jackson reasoned, while in the context 'of the local Brazilian scene' the decision to accept the loss of the contract may make sense, 'so far as the wider industrial scene is concerned', to take this course of action 'may be to prejudice our position elsewhere'. London therefore deemed Charles' acceptance of defeat premature and again opted to raise the case in Washington. ${ }^{52}$

The subsequent British protest to the State Department centered on the fact that the Brazilians had justified breaking negotiations with Metropolitan-Vickers on the grounds that they needed to progress with the work on the railway 'without further delay'. The clear implication of this was that the British company's chief competitor in the country, the Electrical Export Corporation, was in a position to embark on the scheme immediately. This belief appeared contradictory to the previous appraisal of the supply situation given to the Brazilian authorities by the State Department earlier that year. The Foreign Office therefore requested that the State Department dispel any 'misapprehension in the Brazilian minds' and again make clear to the Brazilian government, 'beyond any shadow of doubt', that the same supply conditions that 


\section{Anglo-American Economic Diplomacy during World War II and the Electrification of the Central Brazilian Railway}

afflict Britain also applied to the US. The Foreign Office further expressed its fear to

the State Department that the flow of events in Brazil was leading toward the contract being awarded to the US firm on the pretext of it being completed during the war, but in actuality, for postwar execution. The promises of funding from the Export-Import Bank, moreover, made this outcome all the more likely. The Foreign Office therefore attempted to enlist the State Department's support in preventing the Export-Import Bank from funding the enterprise, seeing this as a violation of the new agreement concerning the protection of British interests. ${ }^{53}$

The State Department certainly understood the linkage between the individual case and the broader principle agreed with Hull. Moreover, there was also an awareness that the agreement protecting British interests was inextricably tied to Britain's ability to participate in a liberal trade system in the postwar era. For the British, as Collado put it, the case was 'was all bound up with the Atlantic Charter and other long range questions, ${ }^{54}$ It was perhaps with such considerations in mind that the Chief of the Division of Commercial Policy and Agreements, Harry Hawkins, suggested that the State Department comply with the British request and make clear to the Brazilians that neither country would be likely to complete the work on the railway sooner than the other. ${ }^{55}$ However, the course of action advocated by Hawkins was only followed to a degree, with Jefferson Caffery, the US Ambassador in Brazil, merely being authorized to clarify the supply situation as it applied to Britain and the US if the Brazilians raised the matter. ${ }^{56}$ Barring this, any misapprehensions concerning US industries' ability to complete work on the central railway sooner than their British competitors, would be allowed to remain. The State Department's attitude toward the activities of the Export-Import Bank was similarly noncommittal, stating only that no formal offer of financial assistance had been made by the bank. ${ }^{57}$ 


\section{Anglo-American Economic Diplomacy during World War II and the Electrification of the Central Brazilian Railway}

This glib response ignored the commitments made by Pierson to support the project the previous year.

The failure on the part of the State Department assertively to enforce the principle agreed to by Hull 'on the ground' in Brazil allowed negotiations between the Electrical Export Corporation and the Brazilian authorities to continue unabated.

Consequently the offer by the US company to carry out the electrification scheme had been accepted by the end of $1943 .{ }^{58}$ Beyond drawing up a contract, the principal hurdle that remained for the interested parties was to gain the backing of the US government to ensure the necessary supplies could be released for the project with a suitable priority rating, and to guarantee financial assistance for the enterprise was forthcoming. Action was thus taken toward the attainment of these goals and on 5 January 1944 Earl C. Givens, the Electrical Export Corporation's Brazilian representative, approached the Economic Counselor at the US Embassy in Rio, Walter J. Donnelly, to request his collaboration in approaching the wartime agencies in Washington responsible for administering supplies. ${ }^{59}$ The next month Guimarães attempted to make use of Pierson's 'great interest' in the electrification project to ensure that he would furnish the Electrical Export Corporation with the necessary financial assistance for the project, should they approach the Export-Import Bank. ${ }^{60}$ The US Embassy in Rio made a similar request of Pierson, outlining its support for the project. $^{61}$

The President of the Export-Import Bank needed little convincing to support the electrification scheme. In a memo on the subject Pierson concluded that there was 'nothing in the history of this project which justifies the United States Government to ask an American firm to relinquish a desirable contract in order to permit a foreign concern to submit a competitive bid now or after the war'. 'The Electrical Export 


\section{Anglo-American Economic Diplomacy during World War II and the Electrification of the Central Brazilian Railway}

Corporation', he therefore concluded, 'should have the vigorous support of all appropriate agencies of this Government' ${ }^{62}$ Based on a narrow legalistic reading of the case's history, Pierson's conclusion may well have been fair. Based on a shortterm understanding of US commercial interests in Brazil, his judgment was surely correct. But Pierson's reading of this case also highlights the Export-Import Bank's complete lack of concern with the broader aims of the State Department concerning Britain and the economic shape of the postwar world. Far from wishing to protect British interests in Brazil, Pierson had reportedly told an official of the British Embassy in Rio that Britain should give up on its commercial interests in the country ${ }^{63}$

Others in Washington were far less belligerent in their attitude toward Britain, and subsequently more equivocal in considering the appropriate action of the US government in this case. D. Maynard Phelps, Associate Chief of the Division of Financial and Monetary Affairs in the State Department, agreed with Pierson that the history of the case provided no particular reason why the Electrical Export Corporation should not gain the contract. Nevertheless, he cautioned that 'it may not be advisable for the Export-Import Bank to finance the orders', or for the State Department 'to support this project in the war agencies'. Phelps advised this restraint in light of the assurance given to Britain by Hull. 'It is a reasonable assumption', he surmised, 'that Metropolitan-Vickers [were] excluded from tendering bids on the materials and equipment needed for electrification ... because of "the exigencies of

the war" ${ }^{64}$ For the US government actively to support the Electrical Export Corporation in gaining this contract, then, would appear to be a violation of the agreement with Britain. 


\section{Anglo-American Economic Diplomacy during World War II and the Electrification of the Central Brazilian Railway}

In May the necessity for the US government to provide financial support for the project was removed when General Electric offered to provide the funding. ${ }^{65}$ This removed the need for the Export-Import Bank to back the project, and thereby nullified one of the problems raised by Phelps. But while government agencies were still in control of supplies during the war, the project could not go ahead without their support. State Department officials were well aware that the Foreign Economic Administration (FEA) and the War Production Board (WPB) would call on their advice once the Electrical Export Corporation requested supplies and an export license to carry out the work in Brazil. By the spring of 1944 supply conditions in the US had eased somewhat and the FEA and WPB confidentially informed the State Department that at least some of the materials needed for the electrification project could probably be scheduled for production in the next few months, and most likely be completed by the first half of 1945. In Britain, conversely, even if supply conditions allowed production of the materials needed, US officials were well aware that the continuing White Paper restrictions on British exports would prevent Metropolitan-Vickers from completing the work so soon. ${ }^{66}$ This situation put the State Department in a position whereby only active opposition would prevent the Electrical Export Corporation from gaining the contract. Such opposition, solely in order to adhere to the agreement with Britain, proved too much to ask.

The State Department subsequently sought a means by which it could quietly aid the Electrical Export Corporation without openly appearing to contradict the pledge made to the British. The solution arrived at was to try and solicit a statement from a high ranking official in the Brazilian government testifying to the importance of the work. In this way the State Department aimed to shift the burden of pressing ahead with the scheme on to the Brazilians and thereby deflect some of the anticipated 


\section{Anglo-American Economic Diplomacy during World War II and the Electrification of the Central Brazilian Railway}

criticism from the British. As Collado put it when instructing Donnelly to extract such a statement from the Brazilians, this 'would be most helpful in conversations with representatives of the British Embassy' ${ }^{67}$ In June the State Department's wish was granted when the Brazilian Minister of Transportation and Public Works, João de Mendonça Lima, expressed his support for the project. ${ }^{68}$

However, the drive to secure the contract for the Electrical Export Corporation was thrown off kilter by an unforeseen internal rivalry from within the Brazilian government between Guimarães and the Brazilian Finance Minister, Artur de Souza Costa. Throughout the summer of 1944 it had slowly become clear to the State Department that the contract between the Electrical Export Corporation and the Brazilian authorities had not been fully cleared in Rio due to the refusal of Souza Costa to support it. ${ }^{69}$ But by this time the State Department was fully committed to seeing the contract go to the US company and was not going to let its efforts be stalled by the internal conflicts of Brazilian politics. It therefore sought to force the issue by making it known to the Brazilian authorities that while the materials for the project could not be guaranteed at the present time, the chances of approval would be much slimmer after the war when demands for postwar reconstruction would be great. The clear implication was that it was in Brazil's own interest to support the contract without further delay. ${ }^{70}$

News that the contract had not in fact been fully cleared by the Brazilians was obviously welcomed by the British authorities. On hearing of this development, Sir Donald Gainer, the new British Ambassador in Rio, reported that the door was once again open for Metropolitan-Vickers, but everything now depended on the priority of supplies. ${ }^{71}$ This was welcome news in London, but what Gainer's assessment of the situation ignored were the continuing White Paper restrictions on British exports now 


\section{Anglo-American Economic Diplomacy during World War II and the Electrification of the Central Brazilian Railway}

being administered by the FEA. ${ }^{72}$ The Board of Trade was pessimistic about the prospects of the FEA granting a waiver for the necessary exports for the enterprise, for as they pointed out, the authorities in Washington were unlikely to loosen 'their strangle-hold on the competition for an order which an American company' believed already to be their own. ${ }^{73}$ This prediction proved accurate and the 'stranglehold' that the US authorities had on the British competition for the scheme while the war continued was surely a further factor fuelling the urgency with which the State Department now pursued the contract.

Having failed to force the Brazilian government's hand by forecasting the difficulties they might encounter in securing supplies in the postwar period, the issue was again pressed when a representative of the Brazilian Embassy in Washington was summoned to the State Department on 11 October 1944. At this meeting, held to seek clarification of the status of the contract in Brazil, Phelps made it perfectly clear that the State Department was 'quite willing to aid the Brazilian Government in securing the equipment' for the electrification work, and in all likelihood the application would be successful. But this could not happen, stressed Phelps, while the State Department remained 'somewhat confused in regard to the attitude of the Brazilian Government' toward the contract. ${ }^{74}$ This message was relayed in Rio and a few days later the Brazilian Minister of Finance discounted his previous misgivings and expressed his full support for the contract with the Electrical Export Corporation. ${ }^{75}$ With all agencies now supporting the scheme, both in Brazil and the US, the contract was finally signed on 29 December $1944 .^{76}$

The British authorities were offered some consolation when MetropolitanVickers eventually gained a contract to supply equipment for future electrification work to be carried out on the Brazilian railway. ${ }^{77}$ The fact that the British company 


\section{Anglo-American Economic Diplomacy during World War II and the Electrification of the Central Brazilian Railway}

was able to retain at least a portion of the work is indicative of the importance the British government attached to maintaining significant markets in Brazil for the postwar period. But the US success at encroaching upon this formerly British contract is representative of the more general trend during World War II of the US consolidating its economic predominance in Brazil at the expense of British interests.

The attempt by the Foreign Office to protect Metropolitan-Vickers' enterprise from their US competitors in Brazil required a coordinated and concerted response across all agencies of the US government. This would have maintained the British market in Brazil for the duration of the war and aided Britain in participating in a system in the postwar world based on economic liberalism. As this article has sought to show, this was an effort that the principal proponent of this system, the US State Department, ultimately proved unwilling to implement. By ensuring the project gained the support of the agencies responsible for administering supplies in the US, the State Department breached the agreement with Britain not to seek commercial advantage for US interests at the expense of British commerce.

The failure on the part of the State Department to protect British interests in this case allowed other agencies in the government to take the lead in advancing US interests in Brazil. Foremost among these was the Export-Import Bank. Although ultimately not required to finance the project, the assurances provided by the President of the bank that it would be willing to support the scheme if needs be, were a key factor in winning the contract for the US firm. Throughout its involvement with the case, the Export-Import Bank showed no concern with the State Department's broader efforts to institute a liberal trade system for the postwar world. To the contrary, by tying an enterprise to a US firm by offering to extend credits, the bank actively worked at cross purposes to the kind of liberal trade system that the State 


\section{Anglo-American Economic Diplomacy during World War II and the Electrification of the Central Brazilian Railway}

Department wished to see take shape in the postwar era by excluding British interests from the country. ${ }^{78}$

Clearly the electrification of the central Brazilian railway was only one enterprise, and the loss of this market was not likely to hinder Britain's ability to participate in a liberal trade system to a great extent. But if, as certainly the British authorities believed, the economic diplomacy concerning this enterprise acted as a test case for the principle agreed between the two countries that the conditions of war would not be exploited for commercial advantage, the outcome did not bode well. By failing to uphold the principle agreed with Britain in this case the US endangered British interests generally and thereby denied its ally the export markets it would require to participate effectively in a liberal economic system in the postwar years. Moreover, by creating an impression in the British official mind that the US was not being consistent in its efforts to promote a more liberal trade system for the postwar world, the US government increased the likelihood that Britain would revert to protectionist measures in areas where it had greater freedom of action. This was certainly the reaction provoked within Metropolitan-Vickers when Foy expressed his hope that Britain would one day 'be in a position to embarrass American business within the Empire'. ${ }^{79}$ Such retaliatory measures were anathema to the State Department's plans for a liberal economic order. But they are hardly surprising given the actions of the US government in this case.

To British businessmen and officials in World War II the actions of their US counterparts with regard to the electrification of the central Brazilian railway looked less like an attempt to institute a mutually beneficial liberal trade system for the postwar world, and more like old-fashioned imperial ambition. From the perspective of present day historians, this case highlights the need to continue to modify our 


\section{Anglo-American Economic Diplomacy during World War II and the Electrification of the Central Brazilian Railway}

conception of the imperatives guiding the US in its economic diplomacy with Britain during World War II.

${ }^{1}$ Foreign Relations of the United States [hereafter FRUS], 1941, (Washington DC: USGPO, 1958), Vol.1, pp.367-369. For Anglo-American negotiations concerning point four of the charter, see FRUS, 1941, Vol.1, pp.360-373.

${ }^{2}$ Department of State Bulletin, 28 Feb. 1942 (Washington DC: USGPO, 1942). For the negotiations leading to the Master Lend-Lease Agreement, see FRUS, 1942, Vol.1, pp.525-537.

${ }^{3}$ Cordell Hull, The Memoirs of Cordell Hull (New York: Macmillan, 1948), Vol.1, pp.81-86, 363-365. For further examples of this thesis by officials who participated in wartime diplomacy, see Herbert Feis, The Sinews of Peace (New York: Harper \& Brothers, 1944), ch.3; E. F. Penrose, Economic Planning for Peace (Princeton: Princeton University Press, 1953), ch.1.

${ }^{4}$ Gabriel Kolko, The Politics of War: Allied Diplomacy and the World Crisis of 1943-1945 (London: Weidenfeld and Nicolson, 1968), ch.12, 14; Lloyd C. Gardner, Economic Aspects of New Deal Diplomacy (Madison: University of Wisconsin Press, 1964), pp.173, 275-285. For the original revisionist interpretation of US economic aims during World War II, see William Appleman Williams, The Tragedy of American Diplomacy (New York: W. W. Norton and Company, 1972) (fist published in 1959), ch.5.

${ }^{5}$ For a thorough reinterpretation of the wartime economic diplomacy between Britain and the US, see Randall B. Woods, A Changing of the Guard: Anglo-American Relations, 1941-1946 (Chapel Hill: University of North Carolina Press, 1990). For a case study demonstrating the US failure to adhere to its stated goal of instituting a liberal economic system in its diplomacy with Britain, see Alan P. Dobson, “AA Mess of Potage for your Economic Birthright?” The 1941-42 Wheat Negotiations and Anglo-American Economic Diplomacy', The Historical Journal, 28/3 (1985).

${ }^{6}$ Cooke quoted in Kenneth E. Trombley, The Life and Times of a Happy Liberal: A Biography of Morris L. Cooke (New York: Harper \& Brothers, 1954), pp.215-219; For US aims in Brazil, see R. A. Humphreys, Latin America in the Second World War, Vol.2, 1942-1945 (London: Athlone, 1982), pp.70-71; Frank D. McCann, The Brazilian-American Alliance, 1937-1945 (Princeton: Princeton University Press, 1974), pp.381-386; Gardner, Economic Aspects of New Deal Diplomacy, pp.195-198. 


\section{Anglo-American Economic Diplomacy during World War II and the Electrification of the Central Brazilian Railway}

${ }^{7}$ By 1938 Brazil received 24 percent of its imports from the US, compared to 10 percent from Britain.

See Dick Steward, Trade and Hemisphere: The Good Neighbor Policy and Reciprocal Trade

(Columbia: University of Missouri Press, 1975), p.145.

${ }^{8}$ Jackson to Willis, 26 May 1945, Foreign Office General Correspondence, FO371/44829/AS2769, UK

National Archives, Kew, London [hereafter cited as FO371 with file numbers].

${ }^{9}$ Aide-Memoire from British Embassy in Washington, 9 Jul. 1943, Folder 216, Box 59, The Papers of

Cordell Hull (microfilm copy) [hereafter Hull Papers], Manuscripts Department, Cambridge University

Library, UK; David Green, The Containment of Latin America: A History of the Myths and Realities of the Good Neighbor Policy (Chicago: Quadrangle Books, 1971), p.138.

${ }^{10}$ Guimarães to Gastão Vidigál, 18 Mar. 1944, State Department Decimal File, Record Group 59

832.77/1069, US National Archives, College Park, MD [hereafter cited by decimal reference].

${ }^{11}$ Ibid.

${ }^{12}$ McCann, The Brazilian-American Alliance, p.47; Getúlio Vargas, A Nova Política do Brasil (Rio de Janeiro: Livraria José Olympio Editora, 1938-1947). For more on Vargas, see Paul Frischauer,

Presidente Vargas (Buenos Aries: Anibal Loureiro, 1943); Alzira Vargas do Amaral Peixoto, Getúlio

Vargas, mеи Pai (Rio de Janeiro: Editôra Globo, 1960).

13 'Electrification of Central Railways of Brazil' memo by Pierson, 21 Mar. 1944, 832.77/1084.

${ }^{14}$ Hunt to Fraser, 13 Jun. 1942, FO371/30356/A5848; 'Electrification of Central Railways of Brazil’ memo by Pierson, 21 Mar. 1944, 832.77/1084.

${ }^{15}$ Turner to Nixon, 19 Jun. 1941, FO371/25781/A4895; Perowne to Campbell, 1 Oct. 1941, FO371/25781/A7567; Scott to Leisching, 29 Jan. 1944, FO371/37857/AS424; Rio to Foreign Office [hereafter FO], 4 Feb. 1944, Mather-Jackson minute, 7 Feb. 1944, FO371/37857/AS923.

16 'Brazil Central Railway Electrification Scheme' memo, Apr. 1941, FO371/25781/A2435.

${ }^{17}$ Nosworthy to Magowan, 3 Jan. 1941, FO371/25781/A127; FO to Rio, 19 Apr. 1941, FO371/25781/A2739.

${ }^{18}$ Turner to Mather-Jackson, 27 Jun. 1941, FO371/25781/A4320.

${ }^{19}$ Rio to FO, 19 May 1941, FO371/25781/A3784; Turner to Mather-Jackson, 27 Jun. 1941, FO371/25781/A4320.

20 'Uncle Sucker?' Time, 18 Aug. 1941, FO371/25781/A9761. 


\section{Anglo-American Economic Diplomacy during World War II and the Electrification of the Central Brazilian Railway}

${ }^{21}$ Mather-Jackson minute, 25 Jun. 1942, FO371/30356/A5848.

22 'K' to Rice, 24 Apr. 1941, FO371/25781/A4046; Washington to FO, 4 Jul. 1941,

FO371/25781/A5186. See also Alan P. Dobson, 'The Export White Paper, 10 September, 1941' The

Economic History Review, 39/1 (1986), pp.63-4.

23 'Exporters Charge British Re-sales', New York Times, 6 Jul. 1941, pp.1-2.

${ }^{24}$ House Resolution 266, 9 Jul. 1941, FO371/25990/A6310.

${ }^{25}$ Alan P. Dobson, 'The Export White Paper', p.64; Washington to FO, 18 Jul. 1941, FO371/25989/A5601, Washington to FO, 22 Jul. 1941, FO371/25989/A5728; Cox to Early, 15 Jul. 1941, Lend-Lease Folder, Subject File, President's Secretary's File (microfilm copy) [hereafter PSF], Roosevelt Study Centre, Middelburg, Netherlands. The accusations from US businessmen in fact began before Lend-Lease appropriations to Britain had even begun.

26 'The Seven Hundred and Sixty-fourth Press Conference (Excerpts), 26 August 1941', The Public Papers and Addresses of Franklin D. Roosevelt, 1941: The Call to Battle Stations, Samuel I. Rosenman ed. (New York: Harper \& Brother, 1950), pp.346-347.

${ }^{27}$ Cox to Early, 15 Jul. 1941, Lend-Lease Folder, Subject File, PSF.

${ }^{28}$ FO to Hunt, 10 Jul. 1941, FO371/25781/A5186.

29 'British Restrict Trade Competition with Our Products', New York Times, 15 Jul. 1941, pp.1, 10; 'Reduzidas radicalmente as exportações britanicas para os países latino-americanos ', Jornal do Brasil, 15 Jul. 1941, p.8.

30 'Correspondence Respecting the Policy of His Majesty's Government in Connexion with the Use of Materials Received Under the Lend-Lease Act', Cmd 6331, 10 Sept. 1941, Parliamentary Papers 1940-41, Vol.VIII: United States No.2 (London: HMSO, 1941). For the negotiations between Britain and the US leading up to the Export White Paper, see FRUS, 1941, Vol.III, pp.8-37.

${ }^{31}$ Pole to Eden, 14 Aug. 1941, FO371/25781/A6427; Fraser to Mather-Jackson, 21 Jun. 1941, FO to Rio, 25 Jun. 1941, Mather-Jackson to Hunt, 28 Jun. 1941, FO371/25781/A4320.

${ }^{32}$ Mather-Jackson minute, 18 Aug. 1941, FO371/25781/A6427; Mather-Jackson minute, 22 Sept. 1941, FO371/25781/A7567.

${ }^{33}$ Quoted in David Dimbleby \& David Reynolds, An Ocean Apart: The Relationship between Britain and America in the Twentieth Century (London: Hodder \& Stoughton, 1998), p.138. 


\section{Anglo-American Economic Diplomacy during World War II and the Electrification of the Central Brazilian Railway}

${ }^{34}$ Rio to FO, 23 Sept. 1942, FO371/30356/A8876; Foy to Hunt, 23 Sept. 1942, FO371/30356/A10222.

${ }^{35}$ Rio to FO, 23 Sept. 1942, FO371/30356/A8876; Foy to Nosworthy, 22 Sept. 1942,

FO371/30356/A10222.

${ }^{36}$ Rio to FO, 23 Sept. 1942, FO371/30356/A8876; Caffery to State Department, 30 Nov. 1942, $832.77 / 868$.

${ }^{37}$ Hunt to Fraser, 13 Jun. 1942, FO371/30356/A5848; FO to Rio, 31 Aug. 1942, FO371/30356/A5848.

${ }^{38}$ Fraser to Mather-Jackson, 18 Jun. 1942, Mather-Jackson minute, 25 Jun. 1942, FO371/30356/A5848.

${ }^{39}$ Mather-Jackson to Fraser, 6 Jul. 1942, FO371/30356/A5848.

${ }^{40}$ FO to Rio, 1 Jan. 1944, FO371/33648/A11270.

${ }^{41}$ Washington to FO, 10 Nov. 1942, FO371/30356/A10461; Washington to FO, 12 Nov. 1942, FO371/30356/A10548.

${ }^{42}$ Micou to Lazo, 16 Oct. 1942, Palmer to Benton, 16 Nov. 1942, 832.77/866-1/2; Washington to FO, 12 Nov. 1942, FO371/30356/A10548; Washington to FO, 18 Jan. 1943, FO371/33648/A718.

${ }^{43}$ State Department to Rio, 11 Feb. 1943, 832.77/1020.

${ }^{44}$ Washington to FO, 18 Jan. 1943, FO371/33648/A718

${ }^{45}$ State Department to Rio, 20 Nov. 1942, 832.77/867B; State Department memo, 4 Jan. 1943, $832.77 / 868-1 / 2$.

${ }^{46}$ State Department to Rio, 20 Nov. 1942, 832.77/867B.

${ }^{47}$ Collado memo, 19 Dec. 1942, FW832.77/868-1/2.

${ }^{48}$ Aide-Memoire from British Embassy in Washington, 9 Jul. 1943, Folder 216, Box 59, Hull Papers.

${ }^{49}$ Memo of conversation, 10 Jul. 1943, Folder 216, Box 59, Hull Papers; Washington to FO, 10 Jul. 1943, FO371/33909/A6498.

${ }^{50}$ Mather-Jackson minute, 19 Mar. 1944, FO371/37857/AS1553.

${ }^{51}$ Rio to FO, 18 Jul. 1943, FO371/33648/A6708.

${ }^{52}$ Mather-Jackson minute, 19 Mar. 1944, FO371/37857/AS1553.

${ }^{53}$ Memo, 3 Aug. 1943, FO371/33649/A7411.

${ }^{54}$ Collado to Hawkins and Stinebower, 14 Aug. 1943, 832.77/1020. 


\section{Anglo-American Economic Diplomacy during World War II and the Electrification of the Central Brazilian Railway}

${ }^{55}$ Hawkins to Collado, 17 Aug. 1943, 832.77/1020. Hawkins was Hull's right hand man in the State Department pursuing a more liberal trade system for the postwar world and was no doubt aware of Britain's need to maintain its export trade if it were to participate in such a system. Leroy D. Stinebower, Chief of the Division of Economic Studies, concurred with Hawkins' view. See Stinebower to Collado, 18 Aug. 1943, 832.77/1020.

${ }^{56}$ State Department to Rio, 31 Dec. 1943, 832.77/1050.

${ }^{57}$ Washington to FO, 14 Dec. 1943, FO371/33648/A11270.

${ }^{58}$ Guimarães to Representative of the Electrical Export Corporation, 30 Dec. 1943, 832.77/1056. For details of the work to be undertaken, see Givens to Donnelly, 5 Jan. 1944, 832.77/1056.

${ }^{59}$ Givens to Donnelly, 5 Jan. 1944, 832.77/1056.

${ }^{60}$ Guimaraes to Pierson, 3 Feb. 1944, 832.77/1062.

${ }^{61}$ Rio to State Department, 22 Mar. 1944, 832.77/1069.

62 'Electrification of Central Railways of Brazil' memo by Pierson, 21 Mar. 1944, 832.77/1084.

${ }^{63}$ Humphreys, Latin America in the Second World War, pp.77, 243n. On another occasion Pierson gave Metropolitan-Vickers' Brazilian representative the impression that his company were viewed as intruders in Brazil. See Foy to Turner, 8 May 1941, FO371/25781/A6427.

${ }^{64}$ Office memo for Collado and Pasvolsky, 6 Apr. 1944, 832.77/1084.

${ }^{65}$ Office memo by Phelps for Hawkins, 11 May 1944, 832.77/1090.

${ }^{66}$ Office memo by Phelps for Collado and Pasvolsky, 6 Apr. 1944, 832.77/1084.

${ }^{67}$ Collado to Donnelly, 25 May 1944, 832.77/1090. See also memo by Duggan for Collado and Berle, 18 Apr. 1944, 832.77/1085.

${ }^{68}$ Rio to State Department, 22 Jun 1944, 832.77/6-2244.

${ }^{69}$ Phelps memo, 6 Apr. 1944, 832.77/1084; Collado to Donnelly, 22 May 1944, 832.77/1090; Phelps memo, 21 Jun. 1944, 832.77/6-1344; Phelps memo, 15 Jul. 1944, 832.77/6-2244; Rio to State Department, 21 Aug. 1944, 832.77/8-2144.

${ }^{70}$ Phelps memo, 15 Jul. 1944, State Department to Rio, 22 Jul. 1944, 832.77/6-2244. This prediction did in fact turn out to be correct, as resources were diverted away from Latin America to Europe, most notably in the form of Marshall Aid. See David Green, 'The Cold War comes to Latin America' in 


\section{Anglo-American Economic Diplomacy during World War II and the Electrification of the Central Brazilian Railway}

Cold War Critics: Alternatives to American Foreign Policy in the Truman Years, Thomas G. Patterson ed. (Chicago: Quadrangle Books, 1971), pp.157, 172.

${ }^{71}$ Rio to FO, 15 Aug. 1944, FO371/37857/AS4373.

${ }^{72}$ Mather-Jackson minute, 17 Aug. 1944, FO371/37857/AS4373.

${ }^{73}$ Willis to Mather-Jackson, 19 Sept. 1944, FO371/37857/AS4987.

${ }^{74}$ Memo of conversation, 11 Oct. 1944, 832.77/10-1144.

${ }^{75}$ Greenwood to Donnelly, 16 Nov. 1944, 832.77/11-1644.

${ }^{76}$ Rio to State Department, 29 Dec. 1944, 832.77/12-2944.

${ }^{77}$ Hunt to Mather-Jackson, 17 May 1945, FO371/44829/AS2461; Rio to FO, 10 Jul. 1945, Willis to Hunt, 12 Jul. 1945, Hunt to Allen 20 Jul. 1945, FO371/44829/AS3633. For details of the equipment to be supplied by Metropolitan-Vickers, see King to Mather-Jackson, 27 Feb. 1945,

FO371/44829/AS1580.

${ }^{78}$ For discussion of the conflicting interests of the Export-Import Bank and the State Department, see Steward, Trade and Hemisphere, ch.9.

${ }^{79}$ Foy to Pole, 10 Sept. 1941, FO371/25781/A9761. 